\title{
Documentation of Caddo Vessels from Red River Sites in Bowie and Red River Counties, Texas, in the Collections of the Sam Noble Oklahoma Museum of Natural History
}

Timothy K. Perttula

Heritage Research Center, Stephen F. Austin State University

Mark Walters

Heritage Research Center, Stephen F. Austin State University

Bo Nelson

Heritage Research Center, Stephen F. Austin State University

Follow this and additional works at: https://scholarworks.sfasu.edu/ita

Part of the American Material Culture Commons, Archaeological Anthropology Commons, Environmental Studies Commons, Other American Studies Commons, Other Arts and Humanities Commons, Other History of Art, Architecture, and Archaeology Commons, and the United States History Commons

Tell us how this article helped you.

This Article is brought to you for free and open access by the Center for Regional Heritage Research at SFA ScholarWorks. It has been accepted for inclusion in Index of Texas Archaeology: Open Access Gray Literature from the Lone Star State by an authorized editor of SFA ScholarWorks. For more information, please contact cdsscholarworks@sfasu.edu. 


\section{Documentation of Caddo Vessels from Red River Sites in Bowie and Red River Counties, Texas, in the Collections of the Sam Noble Oklahoma Museum of Natural History \\ Creative Commons License \\ (c) (1) (9)}

This work is licensed under a Creative Commons Attribution-NonCommercial 4.0 International License 


\title{
Documentation of Caddo Vessels from Red River Sites in Bowie and Red River Counties, Texas, in the Collections of the Sam Noble Oklahoma Museum of Natural History
}

\author{
Timothy K. Perttula, Mark Walters, and Bo Nelson
}

\begin{abstract}
Introduction
We recently had the opportunity to document three ancestral Caddo ceramic vessels from Red River Caddo sites in Bowie and Red River counties, Texas, that are held by the Sam Noble Oklahoma Museum of Natural History. Only one vessel is from a known and recorded site: Bentsen-Clark (41RR41, see Banks and Winters 1975).
\end{abstract}

\section{Documented Ceramic Vessels}

SITE NAME OR SITE NUMBER: None; believed to be from an as yet unknown Bowie County, Texas site VESSEL NO.: TX-70

VESSEL FORM: Jar

NON-PLASTICS AND PASTE: grog

RIM AND LIP FORM: Everted rim and rounded lip

CORE COLOR: G (fired in a reducing environment and cooled in the open air)

INTERIOR SURFACE COLOR: dark grayish-brown

EXTERIOR SURFACE COLOR: dark yellowish-brown; fire clouds on the rim, body, and base

WALL THICKNESS (IN MM): rim, $7.0 \mathrm{~mm}$

INTERIOR SURFACE TREATMENT: smoothed

EXTERIOR SURFACE TREATMENT: none

HEIGHT (IN CM): 23.2

ORIFICE DIAMETER (IN CM): 14.6

DIAMETER AT BOTTOM OF RIM OR NECK (IN CM): 13.2

BASE DIAMETER (IN CM) AND SHAPE OF BASE: $9.5 \mathrm{~cm}$, circular and flat

ESTIMATED VOLUME (IN LITERS): 3.0

Journal of Northeast Texas Archaeology, Volume 76, 2017 
DECORATION (INCLUDING MOTIF AND ELEMENTS WHEN APPARENT): The rim has three horizontal neck banded rows (Figure 1). The vessel body has four vertical appliqued ridges and four appliqued ridge chevron elements.

PIGMENT USE AND LOCATION ON VESSEL: none

TYPE AND VARIETY (IF KNOWN): Nash Neck Banded, grog variety (see Perttula 2015; Suhm and Jelks 1962:111 and Plate 56)

SITE NAME OR SITE NUMBER: None. The vessel came from a burial excavated by Graham Carr of Idabel, Oklahoma. The site is described as being on the Red River, opposite old Shawneetown.

VESSEL NO.: TX-23/1 [tag], labeled TX 41/1

VESSEL FORM: Globular jar with opposed suspension holes ( $3.1 \mathrm{~mm}$ in diameter) on the rim

NON-PLASTICS AND PASTE: shell

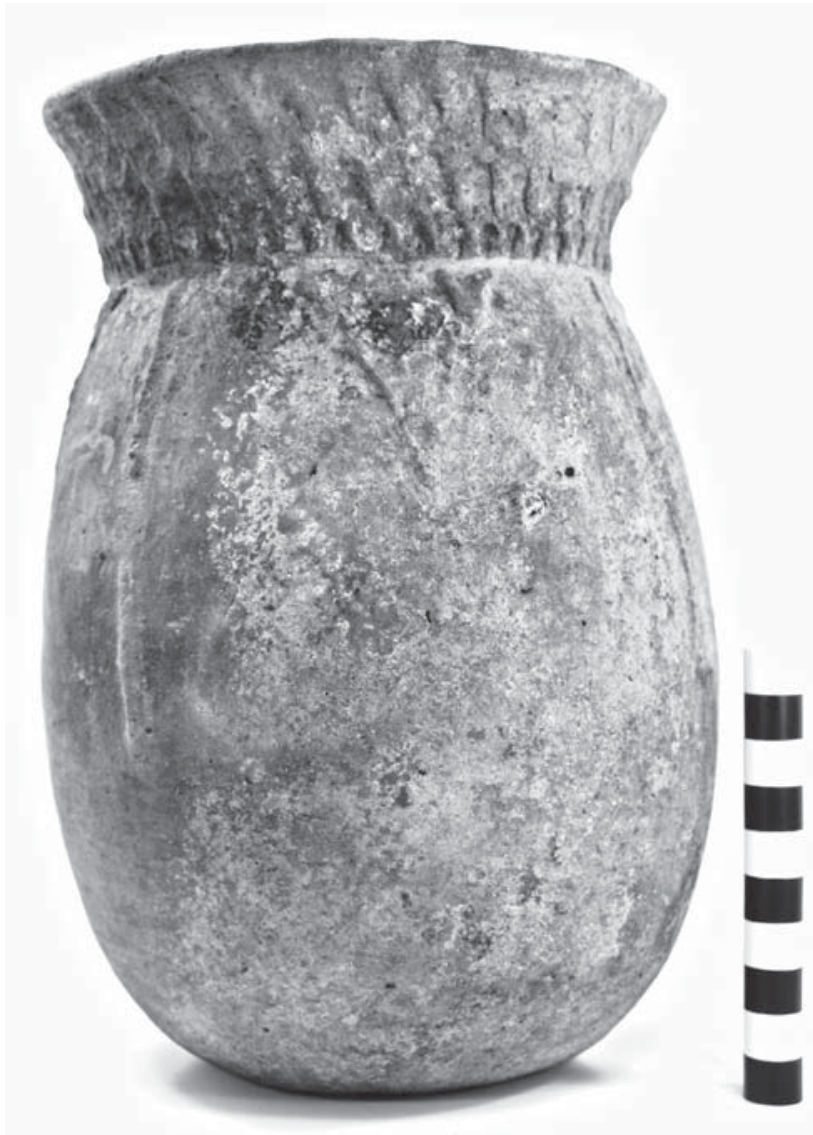

Figure 1. Nash Neck Banded jar, TX-70.

RIM AND LIP FORM: Everted rim and rounded lip

CORE COLOR: B (fired and cooled in a reducing environment)

INTERIOR SURFACE COLOR: dark grayish-brown; fire clouds on the rim, body, and base

EXTERIOR SURFACE COLOR: dark grayish-brown; fire clouds on the rim and body

WALL THICKNESS (IN MM): rim, $5.2 \mathrm{~mm}$

INTERIOR SURFACE TREATMENT: burnished on the rim and smoothed on the body

EXTERIOR SURFACE TREATMENT: burnished

HEIGHT (IN CM): 12.0

ORIFICE DIAMETER (IN CM): 10.4

DIAMETER AT BOTTOM OF RIM OR NECK (IN CM): 9.5

BASE DIAMETER (IN CM) AND SHAPE OF BASE: $7.5 \mathrm{~cm}$, circular and convex

ESTIMATED VOLUME (IN LITERS): 0.7 
DECORATION (INCLUDING MOTIF AND ELEMENTS WHEN APPARENT): The rim of the vessel is plain, but the vessel body has broad hooked arm engraved line elements forming upper and lower zones filled with cross-hatched engraved lines (Figure 2). The upper and lower engraved zones have open triangle elements that separate the hooked arm zones.

PIGMENT USE AND LOCATION ON VESSEL: white and red clay pigments in the engraved lines; the top band of cross-hatching has a red pigment, while the lower band of cross-hatched lines has a white pigment

TYPE AND VARIETY (IF KNOWN): Hudson Engraved (Suhm and Jelks 1962:Plate 41)

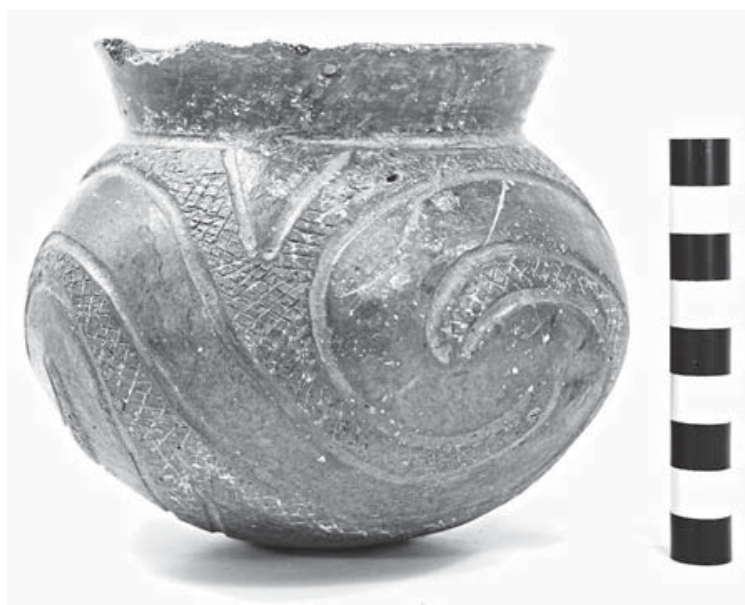

Figure 2. Hudson Engraved jar (TX 23/1) from an unknown Red River County, Texas site.

SITE NAME OR SITE NUMBER: Bentsen-Clark (41RR41)

VESSEL NO.: TX 67/3

VESSEL FORM: Bottle

NON-PLASTICS AND PASTE: grog

RIM AND LIP FORM: N/A

CORE COLOR: G (fired in a reducing environment and cooled in the open air)

INTERIOR SURFACE COLOR: very dark gray

EXTERIOR SURFACE COLOR: red

WALL THICKNESS (IN MM): rim, $6.5 \mathrm{~mm}$

INTERIOR SURFACE TREATMENT: none

EXTERIOR SURFACE TREATMENT: burnished

HEIGHT (IN CM): 12.1+

ORIFICE DIAMETER (IN CM): N/A

DIAMETER AT BOTTOM OF RIM OR NECK (IN CM): N/A

BASE DIAMETER (IN CM) AND SHAPE OF BASE: N/A

ESTIMATED VOLUME (IN LITERS): N/A 
DECORATION (INCLUDING MOTIF AND

ELEMENTS WHEN APPARENT): The exterior vessel surface has a red ochre-rich clay slip

(Figure 3).

\section{PIGMENT USE AND LOCATION ON VESSEL:} none

TYPE AND VARIETY (IF KNOWN): Sanders Slipped (see Perttula et al. 2016)

\section{Summary}

During the course of documenting ancestral Caddo ceramic vessels and other artifacts in the George T. Wright collection from East Texas sites held by the Sam Noble Oklahoma Museum of Natural History at the University of Oklahoma (Perttula et al. 2017), we had the opportunity to document three vessels from different sites in Red River and Bowie counties, Texas. Only one of these vessels is from a recorded site, namely the Bentsen-Clark site (41RR41).

The vessel from the Bentsen-Clark site is a red-slipped Sanders Slipped bottle likely dating to the Middle Caddo period, from ca. A.D. 1200-1400. Banks and Winters (1975:75) note that red-slipped vessels are relatively common at the site, either with engraved lines (Holly Fine Engraved and Spiro Engraved) or as undecorated "Sanders Plain" bottles; Perttula et al. (2016) have re-classified red-slipped Sanders Plain vessels as Sanders Slipped.

The other two vessels are Late Caddo period in age, dating from ca. A.D. 1400-1680. The grogtempered variety of Nash Neck Banded is associated with Texarkana phase sites in Bowie and Cass counties, Texas, while the shell-tempered Hudson Engraved jar is from a late McCurtain phase (ca. A.D. 1550-1680) burial feature in a mid-Red River basin site.

\section{Acknowledgments}

We thank Dr. Marc Levine and Dr. Susie Fishman-Armstrong of the Sam Noble Oklahoma Museum of Natural History for facilitating access to these vessels from East Texas archeological sites, and providing work space during our documentation efforts. We are equally grateful for the support provided by the Caddo Nation of Oklahoma for this documentation effort, and we very much appreciate the visit from Phil Cross (Tribal Historic Preservation Officer and NAGPRA Director) of the Caddo Nation during our work.

\section{References Cited}

Banks, L. D. and J. Winters

1975 The Bentsen-Clark Site, Red River County, Texas: A Preliminary Report. Special Publication No. 2. Texas Archeological Society, San Antonio.

Perttula, T. K.

2015 Caddo Ceramic Vessels from the Hatchel Site (41BW3) on the Red River in Bowie County, Texas. Special Publication No. 39. Friends of Northeast Texas Archaeology, Austin and Pittsburg. 
Perttula, T. K., M. Walters, and B. Nelson

2016 Caddo Ceramic Vessels from the T. M. Sanders Site (41LR2) on the Red River in Lamar County, Texas. Special Publication No. 41. Friends of Northeast Texas Archaeology, Austin and Pittsburg.

2017 Documentation of Ancestral Caddo Ceramic Vessels and Other Artifacts from East Texas Sites in the George T. Wright Collection at the Sam Noble Oklahoma Museum of Natural History. Special Publication No. 49. Friends of Northeast Texas Archaeology, Pittsburg and Austin.

Suhm, D. A. and E. B. Jelks (editor)

1962 Handbook of Texas Archeology: Type Descriptions. Special Publication No. 1, Texas Archeological Society, and Bulletin No. 4, Texas Memorial Museum, Austin. 